\title{
Ground-based remote sensing of an elevated forest fire aerosol layer at Whistler, BC: implications for interpretation of mountaintop chemistry
}

\author{
I. G. McKendry ${ }^{1}$, J. Gallagher ${ }^{1}$, P. Campuzano Jost ${ }^{2}$, A. Bertram ${ }^{2}$, K. Strawbridge ${ }^{3}$, R. Leaitch ${ }^{4}$, and \\ A. M. Macdonald ${ }^{4}$ \\ ${ }^{1}$ Department of Geography, The University of British Columbia, Vancouver, Canada \\ ${ }^{2}$ Department of Chemistry, The University of British Columbia, Vancouver, Canada \\ ${ }^{3}$ Centre for Atmospheric Research Experiments, Environment Canada, Egbert, Canada \\ ${ }^{4}$ Science and Technology Branch, Environment Canada, Toronto, Canada
}

Received: 19 July 2010 - Published in Atmos. Chem. Phys. Discuss.: 27 August 2010

Revised: 18 November 2010 - Accepted: 2 December 2010 - Published: 14 December 2010

\begin{abstract}
On 30 August 2009, intense forest fires in interior British Columbia (BC) coupled with winds from the east and northeast resulted in transport of a broad forest fire plume across southwestern BC. The physico-chemical and optical characteristics of the plume as observed from Saturna Island (AERONET), CORALNet-UBC and the Whistler Mountain air chemistry facility were consistent with forest fire plumes that have been observed elsewhere in continental North America. However, the importance of three-dimensional transport in relation to the interpretation of mountaintop chemistry observations is highlighted on the basis of deployment of both a CL31 ceilometer and a single particle mass spectrometer (SPMS) in a mountainous setting. The SPMS is used to identify the biomass plume based on levoglucosan and potassium markers. Data from the SPMS are also used to show that the biomass plume was correlated with nitrate, but not correlated with sulphate or sodium. This study not only provides baseline measurements of biomass burning plume physico-chemical characteristics in western Canada, but also highlights the importance of lidar remote sensing methods in the interpretation of mountaintop chemistry measurements.
\end{abstract}

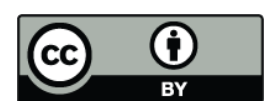

Correspondence to: I. G. McKendry (ian@geog.ubc.ca)

\section{Introduction}

Biomass burning plays an important role in the climate system and is the second largest source of anthropogenic aerosols (IPCC, 2007a). Aerosols produced from the burning of forests, grasslands and crops scatter and absorb solar radiation (direct effect) while also influencing cloud processes by acting as cloud condensation nuclei (indirect effect). Biomass burning also is a source of air pollution and may seriously degrade visibility regionally (e.g. Pahlow et al., 2005). Regional forest fires were a dominant feature of the summers of 2008 and 2009 in western North America and are predicted to increase in frequency and severity under global warming scenarios (IPCC, 2007b).

Physical, chemical and optical properties of biomass burning plumes have been studied extensively in a variety of global settings. This work is exhaustively reviewed by Reid et al. (2005a, b). In summary, approximately $80-90 \%$ of smoke aerosol volume is typically in the accumulation mode (particle diameter $<1 \mu \mathrm{m}$ ) with smoke particles primarily composed of organic carbon (50-60\%) and black carbon (5$10 \%)$. However, the properties of smoke vary between fires, and are dependent on such variables as fuel type and moisture, combustion phase, and wind conditions. Furthermore, the physical, chemical, and optical properties of biomassburning aerosols can change rapidly as they disperse. Typically, aged smoke particles are larger and more spherical than their fresh counterparts (Reid et al., 2005a). For example, aged particles typically have mean diameters ranging from $0.12-0.23 \mu \mathrm{m}$, with a mean around $0.18 \mu \mathrm{m}$, whereas

Published by Copernicus Publications on behalf of the European Geosciences Union. 
fresh particles typically have a mean diameter of $0.12 \mu \mathrm{m}$. Additionally, the absorbing properties of smoke particles are altered by ageing (Amiridis et al., 2009).

As with other sources of transported aerosol, such as volcanic and desert aerosols, smoke plumes are subject to meteorological processes that tend to concentrate plumes into layer structures (McKendry and Lundgren, 2000). Previous studies in southwestern Canada indicate that crustal dust plumes from both Asia and the Saharan desert are subject to large scale subsidence (McKendry et al., 2007, 2008) and mountain wave activity (Hacker et al., 2001), whilst regional smoke plumes from California can be trapped by midtropospheric inversions (McKendry et al., 2010).

Development of pollutant layers and their vertical movement has important implications for the interpretation of chemistry data from mountaintop observatories. At such stations, which are frequently assumed to be in the free troposphere (FT), considerable effort is directed at identifying boundary layer (BL) influences. This is often based on the interpretation of diurnal variability in various entities deemed to be BL tracers such as water vapour, or short-lived chemical species (e.g. Obrist et al., 2008; Weiss-Penzias et al., 2006; Baltensperger et al., 1997). Furthermore, calculation of FT horizontal pollutant fluxes from mountaintop chemistry data assumes that once BL influences are excluded, horizontal advection dominates. Horizontal fluxes of pollutants might therefore be reasonably estimated on the basis of horizontal wind speeds stratified by trajectory (i.e. pollutant concentration $x$ wind speed represents a flux with units $\mathrm{g} \mathrm{m}^{-2} \mathrm{~s}^{-1}$ ).

Herein, a multi-day smoke episode at Whistler, British Columbia (BC) is documented on the basis of observations of mountaintop chemistry at Whistler Mountain, novel deployment of a mountainside mini-lidar (Vaisala CL31 Ceilometer) and ancilliary remote sensing data (lidar and sunphotometer) from Vancouver and Saturna Island. Primary objectives of this combined meteorological and chemical analysis are to:

- Show the critical importance of three dimensional transport processes at different scales in interpretation of mountain-top chemistry observations.

- Characterize the physico-chemical and optical characteristics of regional scale plumes in southwestern BC using lidar and single particle mass spectrometry.

- Demonstrate the utility of remote vertical profiling methodologies to the interpretation of mountaintop chemistry observations.

This study is part of a wider project designed to better understand atmospheric aerosol in this region, to better understand trans-Pacific transport of pollution from Asia to Western Canada and to improve understanding of the chemical properties of aerosols in the lower FT.

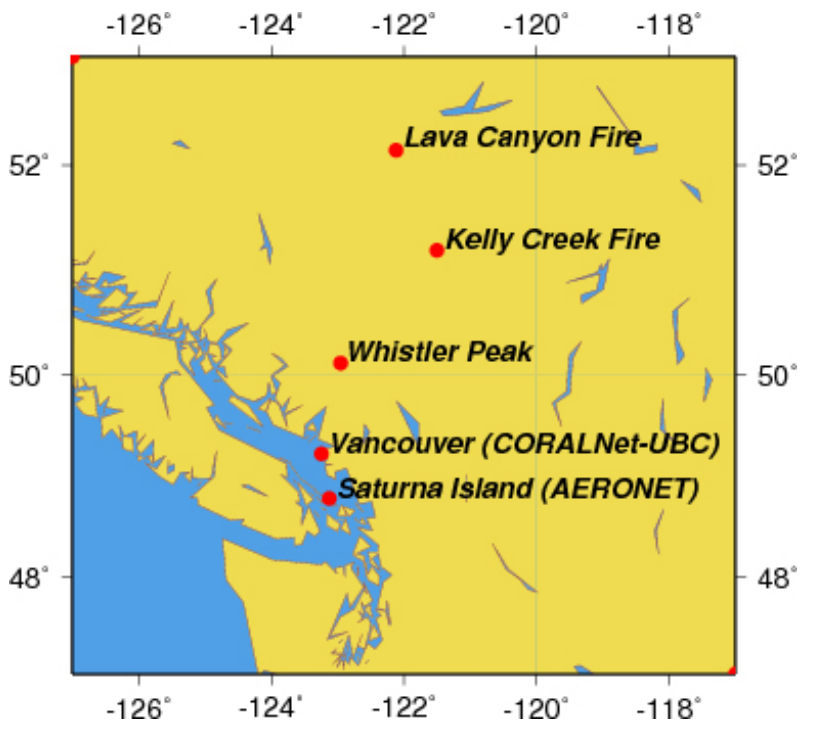

Fig. 1. Map showing places mentioned in the text.

\section{Methods}

\subsection{Ceilometer}

The Vaisala CL31 ceilometer is described in detail in Münkel et al. (2007). Briefly, the eye-safe instrument has a 5 to $10 \mathrm{~m}$ resolution, 0-7500 $\mathrm{m}$ range and produces a light source of wavelength $910 \mathrm{~nm}$ from a laser diode. The CL31 uses a single-lens design in which the central portion of the lens is used for collimating the outgoing laser beam, while the outer part of the lens is used for focusing the backscattered light onto the receiver. For this study, the ceilometer was operated at the maximum vertical resolution of $5 \mathrm{~m}$ with a measurement interval of $3 \mathrm{~s}$ and a reporting interval of $60 \mathrm{~s}$. This temporal resolution was deemed sufficient for analyzing the development of BL structure and lower FT features. Due to the low power of the laser (energy output $1.2 \mu \mathrm{J}$ ) a large number of pulses are automatically averaged for the purpose of noise cancellation. The pulse repetition rate is $10 \mathrm{kHz}$.

Although originally designed to determine cloud heights, in recent years ceilometers have been used for determining BL structure by taking the backscatter intensity of the returned laser light as a proxy for ground-sourced aerosol concentrations (Räsänen et al., 2000; Emeis et al., 2004; Zephoris et al., 2005; van der Kamp et al., 2008; McKendry et al., 2009, 2010). Previous studies in the Vancouver Region (see Fig. 1) have demonstrated the capability of the $C L 31$ for identifying elevated pollutant layers and smoke plumes (McKendry et al., 2009). For this study the ceilometer was deployed at an elevation of $810 \mathrm{~m}$ (a.m.s.l.) on the lower slopes of Whistler Mountain (at the Timing Flats). The ceilometer was installed and operated by Environment Canada as part of a data collection effort related to meteorological services for the 2010 Olympic Winter Games. 


\subsection{Lidar}

Additional regional information on the smoke event was derived from 1064/532 nm lidar observations from the University of British Columbia (UBC) (part of the Canadian Operational Research Lidar Network (CORALNet) - http://www. coralnet.ca/). The lidar systems deployed for CORALNet use identical transmitter and receiver assemblies and where necessary are housed in a modified cargo trailer. The trailer modifications include a roof hatch assembly, basic meteorological tower, radar interlock system, climate control system and leveling stabilizers. The unit can be operated via an internet link and requires an external power source. A precipitation sensor is used to operate the roof hatch, and three pan/tilt webcams capture sky conditions and monitor the lidar system's condition. A remote control interface is used to control all vital components of the system, including the ability to provide hard resets of the laser electronics.

The laser is a Continuum Inlite III (small footprint) laser operating at $1064 / 532 \mathrm{~nm}$ with a pulse repetition rate of $10 \mathrm{~Hz}$. The energy output is approximately $150 \mathrm{~mJ} @ 532 \mathrm{~nm}$ and $130 \mathrm{~mJ} @ 1064 \mathrm{~nm}$. The system emits two wavelengths and measures a return signal at three channels (1064 nm, 532 both polarizations). The lidar system is located at an elevation of $78 \mathrm{~m}$ a.m.s.l. on the UBC Point Grey campus just west of the city of Vancouver (Fig. 1).

\subsection{Single Particle Mass Spectrometer (SPMS)}

An ion trap based single particle MS was built for deployment at the top of Whistler Mountain. This instrument follows broadly the design principles of the UT-ATOFMS described by Su et al. (2004). As in that instrument, the SPMS incorporates (a) an aerosol lens as a vacuum interface, particle concentrator and focusing device, (b) dual aerosol scattering devices operating at $532 \mathrm{~nm}$ for aerosol sizing and mass spectrometer triggering and (c) a pulsed dual polarity mass spectrometer incorporating an ablation/ionization laser operating at $266 \mathrm{~nm}$ for ionization of the particles. While the details of the instrument are discussed in a separate publication (Campuzano-Jost and Bertram, 2010), the main differences compared to the ATOFMS relevant to this study are briefly listed here:

- Aerosol sizing module is fully independent of mass spectrometer operation, allowing the acquisition of full particle distributions to compare with standard aerosol instrumentation (Simpson et al., 2009).

- A real-time triggering solution for the ionization laser that ensures consistent beam quality and hence greatly reduces shot to shot fluctuations (Hanna et al., 2009).

- An ionization region about four times larger than in the Su et al. (2009) design, which should improve MS collection efficiency in some cases.
- A 3-D ion trap for mass analysis. This results in a smaller footprint MS module with a robust mass calibration, high sensitivity, and reduced space charge effects. It also allows for tandem mass spectrometry (Simpson et al., 2009), which was not used in this study.

While the full mass range of the ion trap MS is roughly 10 $200 \mathrm{~m} / \mathrm{z}$, for the data acquired for this paper only a reduced mass range of $10-100 \mathrm{~m} / \mathrm{z}$ was used. This limits somewhat the analysis of more complex smoke markers.

\subsection{Whistler mountaintop chemistry}

Measurements of particles and trace gases are made at a high elevation site in Whistler, BC, approximately $100 \mathrm{~km}$ north of Vancouver (Fig. 1). The site is located at the top of a ski resort on Whistler Mountain, at a height of $2182 \mathrm{~m}$ (a.m.s.1.) and is operated by Environment Canada. There are no continuous combustion sources at the peak and occasional influences from maintenance vehicles operating on the mountain have been identified and removed from the data set.

Condensation nuclei $(\mathrm{CN})$ are observed using a TSI 3025 Ultrafine Condensation Particle Counter, which measures number concentration of particles larger than approximately $3 \mathrm{~nm}$ diameter. The TSI 3025 uses butanol as a condensing fluid to enlarge the particles to a size that can be detected by an optical sensor. Particle size distributions are measured using a MSP Corporation Wide Range Aerosol Spectrometer, which combines a differential mobility analyzer and an optical particle counter to measure from about $0.01 \mu \mathrm{m}$ to $20 \mu \mathrm{m}$ diameter. Here, we use only the number concentrations of greater than about $0.4 \mu \mathrm{m}$ diameter.

\subsection{Saturna Island sunphotometer}

AEROCAN CIMELs (AEROCAN is the Canadian subnetwork of AERONET) have been important in tracing the transport and characteristics of aerosol layers over British Columbia and, in general, over AEROCAN/AERONET sites across North America (e.g. Thulasiraman et al., 2002). The AEROCAN site on Saturna Island site (Fig. 1) is approximately $50 \mathrm{~km}$ southwest of Vancouver. The CIMEL sunphotometer instruments acquire solar radiances which are transformed into three processing levels of Aerosol Optical Thickness (AOT) (1.0 - non-cloud screened, 1.5 - cloud screened and 2.0 - cloud screened and quality assured) across eight spectral channels $(340,380,440,500,670,870,1020$ and $1640 \mathrm{~nm})$. In a separate operational mode, almucantar sky radiances are collected across four channels (440, 670, 870, and $1020 \mathrm{~nm}$ ) at a nominal sampling resolution, which is about $1 / 20$ of the nominal AOT sampling resolution (an hour versus $3 \mathrm{~min}$ ). The sky radiances, along with AOT estimates at the same four channels, are used to perform inversions for particle size distribution and refractive index (Dubovik et al., 2000). 


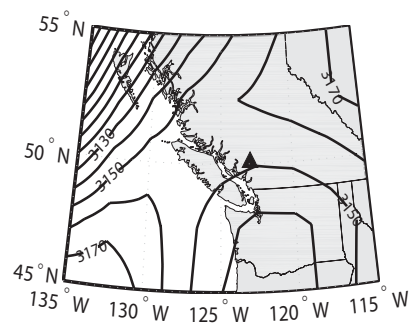

(a) 29 August 2009

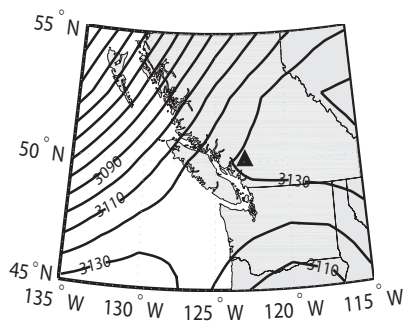

(b) 30 August 2009

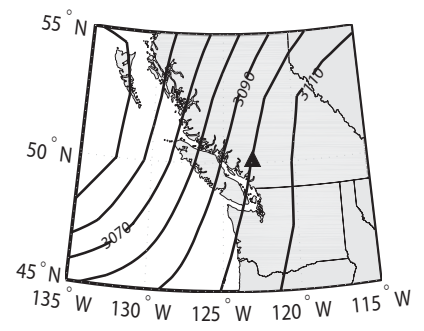

(c) 31 August 2009

Fig. 2. NCEP reanalysis data showing $700 \mathrm{hPa}$ heights (m) from 29-31 August 2009. For each LST day, the height values represent data averaged over the four synoptic observation times. Contour interval $10 \mathrm{~m}$. The location of Whistler Mountain is marked by a solid triangle symbol.

\subsection{Ancilliary data}

To complement aerosol observations from the summit of Whistler Mountain, hourly $\mathrm{PM}_{2.5}$ data were obtained from the BC Ministry of Environment's air quality station in Whistler Valley (Whistler Meadow Park, 641 ma.m.s.l.). Weather maps for the relevant time periods were created from NCEP pressure level reanalysis datasets, available from NOAA's Earth System Research Laboratory (http://www. esrl.noaa.gov/psd/data/gridded/reanalysis).

\section{Results}

\subsection{Synoptic meteorology and fire history}

During summer 2009, persistent large-scale weather patterns in North America were responsible for the unusually warm and dry season experienced in southern BC. For most of the late spring and summer a high pressure ridge persisted aloft over the region, deflecting Pacific frontal systems to the north. Precipitation for the June-August period was well below average: $43 \%$ of normal for Vancouver and $41 \%$ of normal for Whistler (Environment Canada statistics). Record high temperatures were observed in the region in late July, including $34.4^{\circ} \mathrm{C}$ at Vancouver International Airport (an alltime record high). A significant consequence of this weather pattern was the very active forest fire season that occurred in $\mathrm{BC}$ and the northwestern US.

In southwestern British Columbia, in addition to several minor fires, the largest fires (see Fig. 1) were the Kelly Creek Fire near Clinton (reported at 13572 ha on 28 August) and the Lava Canyon Fire near Williams Lake (reported at 33815 ha on 26 August). In addition to numerous large fires east of the Coast Mountains, two small fires were reported on Blackcomb Mountain within a few kilometres of observing sites on Whistler Mountain. Thus, degraded air quality from smoke was a common occurrence throughout the summer in southern BC. At times, easterly to northerly wind flows aloft advected smoke through the Whistler area and into Metro Vancouver.
Synoptic weather patterns during the final three days of August resulted in advection of forest fire smoke from southern British Columbia fires (including Kelly Creek, Notch Hill and Lava Creek) westward to Whistler Mountain. This westward transport was associated with a cyclonic circulation situated over the northwestern United States that was evident in both $500 \mathrm{hPa}$ (not shown here) and $700 \mathrm{hPa}$ patterns (Fig. 2) on 29 and 30 August. On 31 August, the low continued inland as low pressure in the northeast Pacific approached the coast, changing the flow over Whistler to a southerly direction.

Between the inland and offshore cyclonic circulations, a ridge of high pressure was apparent at both $500 \mathrm{hPa}$ and $700 \mathrm{hPa}$. On 30 August, this ridge was oriented southwestnortheast directly over Whistler (Fig. 2b). A maximum in dynamic subsidence (positive $\omega$, expressed in $\mathrm{Pa} \mathrm{s}^{-1}$ ) is found downstream of the ridge axis (Fig. 3a) and centred over southwestern BC. Ceilometer observations (Fig. 5b) show the smoke plume lowering with time at a rate of $\sim 1.7 \mathrm{~cm} \mathrm{~s}^{-1}$ at Whistler over the morning period of 30 August. At the surface, the synoptic scale forcing was rather weak, with a high pressure ridge just offshore of British Columbia (Fig. 3b).

This synoptic pattern explains both the timing of the smoke plume in the Whistler area as well as the apparent vertical motion of the plume that was observed by the Whistler ceilometer. On 29 August, east-northeast winds aloft carried smoke from the inland fires to the Whistler area. On $30 \mathrm{Au}-$ gust, easterly winds continued to advect the smoke plume westward as dynamic subsidence forced the plume to descend at the same time. On 31 August, the flow aloft turned southerly and the smoke gradually retreated to the north.

Satellite derived smoke detection products from the National Environmental Satellite Data and Information Service (NESDIS found online at http://map.ngdc.noaa.gov/website/ firedetects/viewer.htm) show the regional smoke distribution in the period 29-31 August with a wide swath of smoke extending westward to Vancouver in the south and northward into central BC (Fig. 4). 

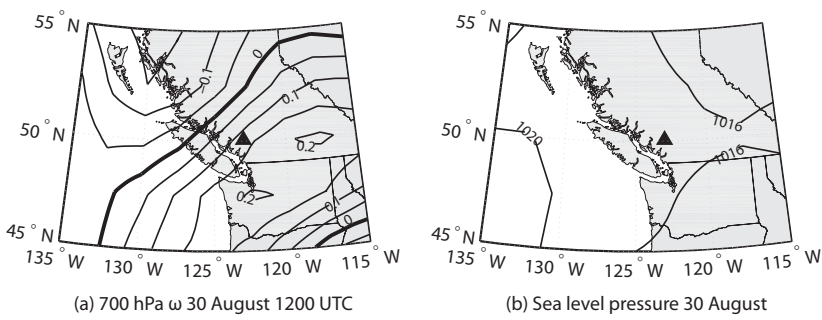

Fig. 3. NCEP reanalysis data from 30 August 2009 showing: (A) the $700 \mathrm{hPa}$ vertical motion field $\left(\mathrm{Pa} \mathrm{s}^{-1}\right.$ ) at 12:00 UTC/04:00 LST, with downward motion indicated by positive $\omega$ values southeast of the bolded zero contour, and (B) the averaged sea level pressure (hPa) pattern for the LST day.

\subsection{Lidar and ceilometer}

The combination of CORALNet-UBC (Vancouver) lidar imagery, Whistler mountainside ceilometer imagery and Whistler mountaintop chemistry measurements provide a novel opportunity to examine both the regional and local scale processes affecting smoke layers. In Fig. 5a, CORALNet-UBC $1064 \mathrm{~nm}$ imagery shows a pattern broadly consistent with that observed by ceilometer at Whistler (Fig. 5b). A dense aerosol layer capped below $3 \mathrm{~km}$ a.g.l. was evident over Vancouver on 30 August 2009. Apparent rates of subsidence $\left(\sim 1.7 \mathrm{~cm} \mathrm{~s}^{-1}\right)$ and midday BL mixing patterns are also similar to those observed by the Whistler ceilometer and suggest that the evolution of the smoke layer at Whistler was characteristic of a broad regional pattern, albeit modified by local topographic effects. The aerosol plume appears to be vertically thicker over the CORALNet lidar than over the Whistler ceilometer, but this is likely due to the ceilometer's lower power-aperture product resulting in significant attenuation of the signal with height. A time series of Aerosol Optical Depth (AOD) from the Saturna Island site is also included (Fig. 5d) to confirm the regional scale of the layer, which was dominated by fine mode aerosols. Although data are only available from daylight hours, it appears as though the AOD values peaked during late morning on 30 August, which is consistent with the other observations.

The plume orientation observed by the ceilometer - sloping downward over time - could have been caused by mechanisms other than subsidence. For instance, vertical wind shear acting on a smoke column would lead to a tilted column, which would appear as a sloped plume. However, in this case, synoptic scale subsidence was a feature of the prevailing weather pattern and the observations are consistent with such a mechanism acting throughout the region (e.g. the large scale of the plume and consistency of patterns evident in both the UBC lidar and Whistler ceilometer data). As the relevant fires were a considerable distance from Whistler, it seems less likely that a sloping feature would retain its coherence through the mountainous terrain that is found between

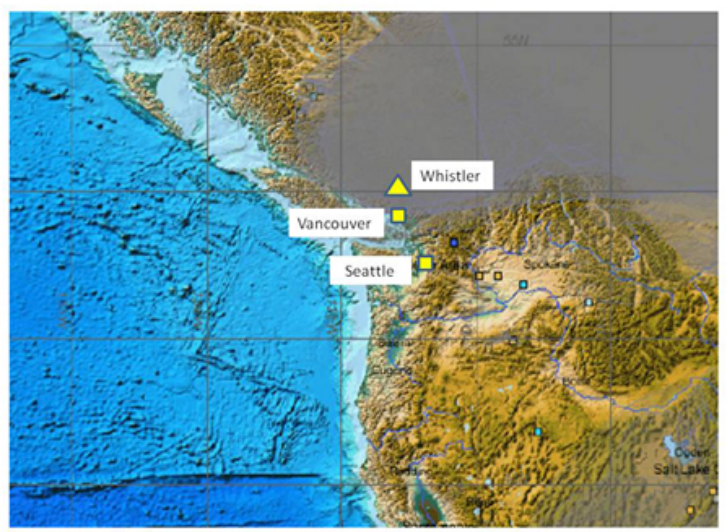

Fig. 4. Satellite smoke detections shown in gray for the period 29-30 August 2009 (courtesy http://map.ngdc.noaa.gov/website/ firedetects/viewer.htm).

the smoke source region, the Whistler ceilometer and the UBC lidar. However, without upstream observations of the smoke plume, a definitive explanation of its evolution is not possible. Regardless of this limitation, this case underlines the importance of using all relevant datasets from the area to assist interpretation of measurements made at the mountaintop observatory.

Whistler mountaintop $\mathrm{CN}$ particle concentrations and nearby valley floor $\mathrm{PM}_{2.5}$ observations (Fig. $5 \mathrm{c}$ ) were negatively correlated over the 30-31 August period. As the layer intercepted the peak at $\sim 03: 00 \mathrm{LST}$ on 30 August, $\mathrm{CN}$ values spiked and then declined rapidly as the layer moved below the elevation of Whistler Peak. On 30 August, valley floor $\mathrm{PM}_{2.5}$ concentrations reached a maximum of $27 \mu \mathrm{g} \mathrm{m}^{-3}$ at 13:00 LST. On 31 August, the highest $\mathrm{PM}_{2.5}$ concentration $\left(26 \mu \mathrm{g} \mathrm{m}^{-3}\right)$ occurred at 08:00 LST, followed by a lesser peak $\left(21 \mu \mathrm{g} \mathrm{m}^{-3}\right)$ at 13:00 LST.

Variations in $\mathrm{PM}_{2.5}$ concentrations evident in Fig. $5 \mathrm{c}$ are likely due to local scale variations in wind and stability. During this period, the weak synoptic scale pressure gradient and clear skies allowed thermally induced mesoscale flows to dominate the wind pattern in Whistler Valley. Diurnally reversing slope and valley winds are common in mountainous terrain under such conditions (Whiteman, 2000). Observations from surface weather stations in the area indicate that diurnal winds occurred during the three days of this study (for brevity, these observations are not presented here). At the valley floor observing location, calm winds were observed in the morning hours, followed by southerly (upvalley) winds in the afternoon, which increased to $\sim 5 \mathrm{~m} / \mathrm{s}$ in the late afternoon. Reports from several of Environment Canada's Olympic Autostation Network (OAN) sites on the slopes of Whistler Mountain also indicated diurnal flows: winds with an easterly (downslope) component occurred 


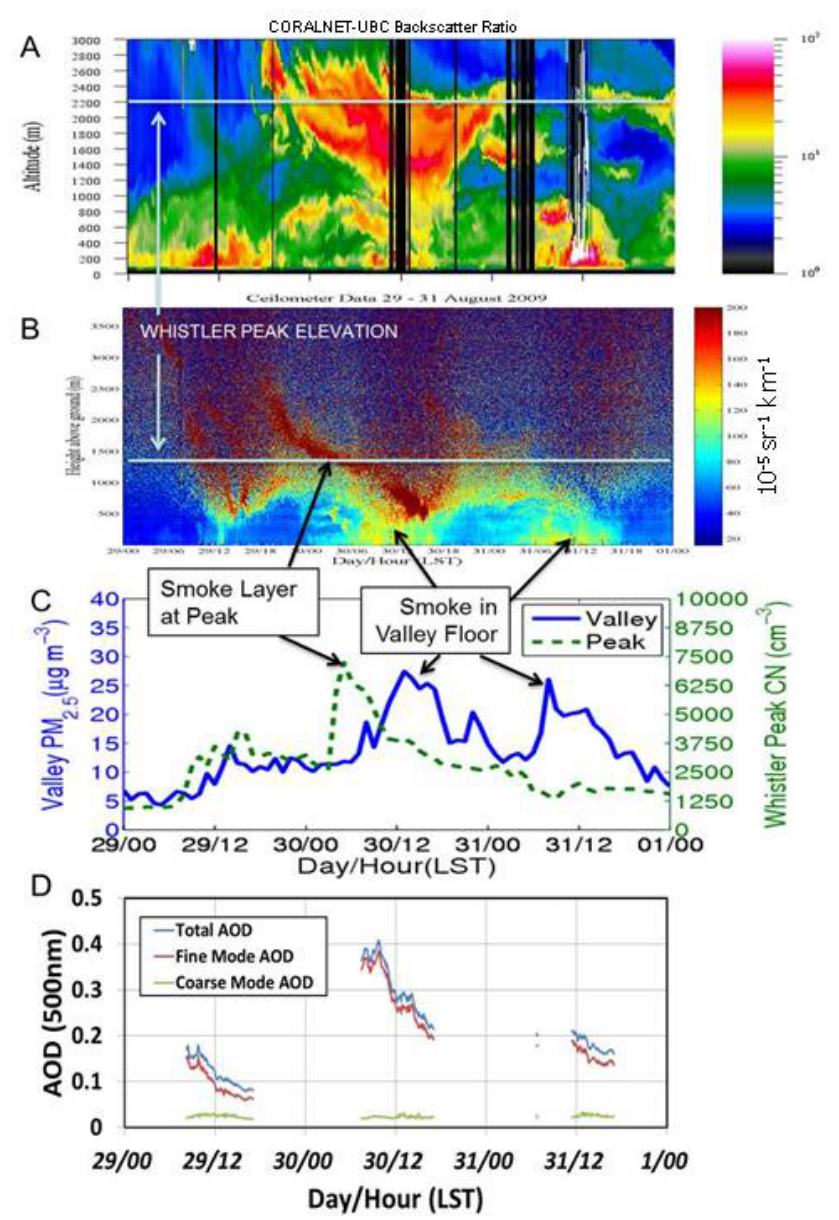

Fig. 5. (A) CORALNet-UBC $1064 \mathrm{~nm}$ backscatter ratio data from Vancouver - red and yellow hues show smoke layer (B) Whistler ceilometer two-way attenuated backscatter profile data - smoke layer depicted in red (C) Whistler Peak CN and Whistler Valley $\mathrm{PM}_{2.5}$ observations and (D) Saturna Island AERONET AOD measurements at $500 \mathrm{~nm}$, divided into fine and coarse mode using Spectral Deconvolution Algorithm (SDA) for the period 29-31 August 2009. Note, because of the instrument elevation differences between the ceilometer and lidar, Whistler Peak elevation (a.g.l.) differs (marked by a horizontal line across each image in panels $\mathbf{A}$ and B).

overnight, and winds with a westerly (upslope) component were dominant during the daytime. Two effects of this wind pattern were likely important to the observed impact of forest fire smoke in the lower elevations of the valley: (1) the slope winds facilitated vertical mixing that was otherwise limited by stable stratification in the lower troposphere; (2) the afternoon up-valley breeze effectively removed much of the smoke from the valley. Evidence for both of these effects can be found in the ceilometer data (Fig. 5b). Enhanced returns in the lowest $500 \mathrm{~m}$ around midday are likely due to PM that was mixed downward out of the main smoke plume. The much lower returns found in the lowest $800 \mathrm{~m}$ after 17:00 LST indicate cleaner air arriving from up-valley flow. Wind observations in the area are limited, but it is likely that, on days with a well-developed valley wind, marine air reaches Whistler from the head of Howe Sound (approximately $35 \mathrm{~km}$ to the south). However, pollutants can be returned to the Whistler Valley during the overnight hours by down-valley winds and ground-level PM concentrations can then increase as the shallow nocturnal boundary layer limits mixing, an effect that explains the morning spike in $\mathrm{PM}_{2.5}$ on 31 August.

\subsection{Optical characteristics and physico-chemical composition of smoke}

Given the regional scope of the smoke event, Saturna Island (Fig. 1) AERONET inversion data provide an appropriate characterization of the optical and physical properties of the 30 August smoke event. These values are presented in Table 1 where they are compared with typical North American biomass burning values as summarized by Reid et al. (2005a). Note, the final four rows describe a bimodal size distribution and show the dominance of the accumulation mode as expected for a forest fire plume. Other optical parameters are remarkably consistent with those reported by Reid et al. (2005a) based on AERONET inversions for North American boreal forest biomass burning aerosol.

The SPMS was operating at Whistler Peak between $22 \mathrm{Au}-$ gust 2009 and 6 September 2009. During this time period, it was only operated during hours when an operator could access it. Therefore the SPMS dataset is limited to daily periods of about 4-6h between roughly 10:00 and 17:00 LST. During the smoke period, roughly 1 million particles were sampled and sized over the three day period $(\sim 20 \mathrm{~h})$. Total particle concentrations acquired by the SPMS show a steep increase in particle concentration with the plume's arrival. They were consistent with data acquired by the OPC operating at Whistler Peak once the detection limit/efficiency of the SPMS was taken into account (Fig. 6, top panel), giving us confidence that the SPMS sampled a representative aerosol distribution.

Mass spectra (161000 for the smoke period) were background corrected and integrated with unit mass resolution. They were then classified as valid aerosol spectra if at least one particular mass showed an ion current at least $4 \times$ above the standard deviation of the noise. Based on this criterion, about 75000 (47\% of acquired) valid MS spectra were included in the final analysis.

The smoke plume was characterized with a variety of wellestablished markers that were computed on a particle-byparticle basis for the fraction of valid mass spectra. In order to account for fluctuations in both ionization efficiency and detector gain, all markers were normalized to the total ion current derived from the particle. Finally, for clarity, daily averages were computed. 
Table 1. Summary Comparison of AERONET daily values for 30 August 2009 at Saturna Island and biomass burning aerosol optical properties from Reid et al. (2005a) summary (Table 3) of worldwide AERONET network of ground-based radiometers. In the right column are boreal forest biomass burning properties from USA and Canada. The middle column shows AERONET daily values for 30 August 2009.

\begin{tabular}{|c|c|c|}
\hline Parameter & $\begin{array}{l}\text { Saturna Island } \\
30 \text { August } 2009\end{array}$ & $\begin{array}{l}\text { USA/Canada Values (or } \\
\text { Range of Values) for } \\
\text { Biomass Burning }\end{array}$ \\
\hline Aerosol Optical Thickness $\left(\tau_{440}\right)$ & 0.41 & $\geq 0.41$ \\
\hline Ångström Exponent $(\alpha)$ & 1.92 & $1.0 \leq \alpha \leq 2.3$ \\
\hline Asymmetry (g) (440/670/870/1020 nm) & $0.66 / 0.57 / 0.52 / 0.51$ & $0.69 / 0.61 / 0.55 / 0.53 \pm 0.66$ \\
\hline $\begin{array}{l}\text { Real and imaginary parts of Refractive } \\
\text { Index }(n: k)\end{array}$ & $1.48 ; 0.004$ & $1.50 \pm 0.04 ; 0.0094 \pm 0.003$ \\
\hline $\begin{array}{l}\text { Single scattering albedo } \\
\left(\omega_{\mathrm{o}}\right)(440 / 670 / 870 / 1020 \mathrm{~nm})\end{array}$ & $0.97 / 0.96 / 0.95 / 0 / 95$ & $0.94 / 0.935 / 0.92 / 0.91 \pm 0.02$ \\
\hline $\begin{array}{l}\text { Volume Median Radius (fine) }(\mu \mathrm{m}) ; \\
\text { Geometric Standard Deviations }\left(\sigma_{\mathrm{gv}}\right)\end{array}$ & $\begin{array}{l}0.15 \\
0.42\end{array}$ & $\begin{array}{l}\left(0.3+0.03 \tau_{440} \pm 0.02\right) / 2 \\
(1.54 \pm 0.04) / 2\end{array}$ \\
\hline $\begin{array}{l}\text { Volume Median Radius (coarse) }(\mu \mathrm{m}) \text {; } \\
\text { Geometric Standard Deviations }\left(\sigma_{\mathrm{gv}}\right)\end{array}$ & $\begin{array}{l}2.51 \\
0.79\end{array}$ & $\begin{array}{l}\left(6.4+0.4 \tau_{440} \pm 0.5\right) / 2 \\
(2.2 \pm 0.4) / 2\end{array}$ \\
\hline $\begin{array}{l}\text { Volume concentration of the fine mode } \\
C_{\mathrm{vf}}\left(\mu \mathrm{m}^{3} / \mu \mathrm{m}^{2}\right)\end{array}$ & 0.05 & $0.01+0.1 \tau_{440} \pm 0.04$ \\
\hline $\begin{array}{l}\text { Volume concentration of coarse mode } \\
C_{\mathrm{vc}}\left(\mu \mathrm{m}^{3} / \mu \mathrm{m}^{2}\right)\end{array}$ & 0.02 & $0.01+0.03 \tau_{440} \pm 0.03$ \\
\hline
\end{tabular}

As for the selection of appropriate markers, according to Reid et al. (2005b) the main tracers of biomass burning are black carbon (positive $m / z, 12 *$ n), potassium (K, positive $m / z$ 39 and 41) and levoglucosan (negative $m / z$ 45, 59, 71). Levoglucosan (1,6-anhydro- $\beta$-D - glucopyranose) is a product of cellulose combustion and is a well-known and stable tracer of biomass burning (Qin et al., 2006 as well as references therein). Aged biomass is also often associated with elevated levels of sulphate (negative $\mathrm{m} / \mathrm{z} 81$ and 97), nitrate (negative $\mathrm{m} / \mathrm{z} 46$ and 62) and organics (Murphy et al., 2006). Finally, sodium (Na, positive $\mathrm{m} / \mathrm{z} 23$ ) has at times been identified in biomass burning plumes, although it seems to be highly dependent on the source of the biomass (Hudson et al., 2004). Figure $6 \mathrm{~b}-\mathrm{f}$ show the daily average ratios of these markers in the smoke plume as well as before and after it with the exception of the organics and black carbon marker. The organics marker (positive $m / z$ 27, 29, 37, see Silva et al., 2001) was discarded due to the aluminum isobar $(\mathrm{m} / \mathrm{z} 27)$, which was likely present in some dust and pollution events before and after the plume. The black carbon marker was discarded due to its poor expression throughout the sampling period. This is likely due to the overlap of other organic fragments (Murphy et al., 2006).
Figure 6 shows that the aerosol chemistry at Whistler Peak did indeed change during the 29-31 August period, with large increases in the relative amounts of potassium and levoglucosan. This is consistent with previous observations of biomass plumes (Qin et al., 2006; Hudson et al., 2004). A significant increase in nitrate was also observed, as would be expected for an aerosol from a source about $100 \mathrm{~km}$ away. On the other hand, another aging marker, sulphate, decreased. This probably simply reflects the high levels of sulphate that were present in the background aerosol both before and after the plume. Lastly, no increase was observed for sodium (the increase of this marker around 4 September is due to an influx of Pacific air at the site). As stated before, this may be just a function of the specific composition of $\mathrm{BC}$ wood and soil.

\section{Discussion and conclusions}

Based on the mountaintop observations of chemical constituents alone, the natural interpretation of the 30 August fire plume would be that the smoke episode was brief. However, lidar and ceilometer data show that smoke was present at elevations both above and below the mountaintop station and persisted over multiple days. Interpretation of time series of chemical constituents at mountaintop sites therefore requires 


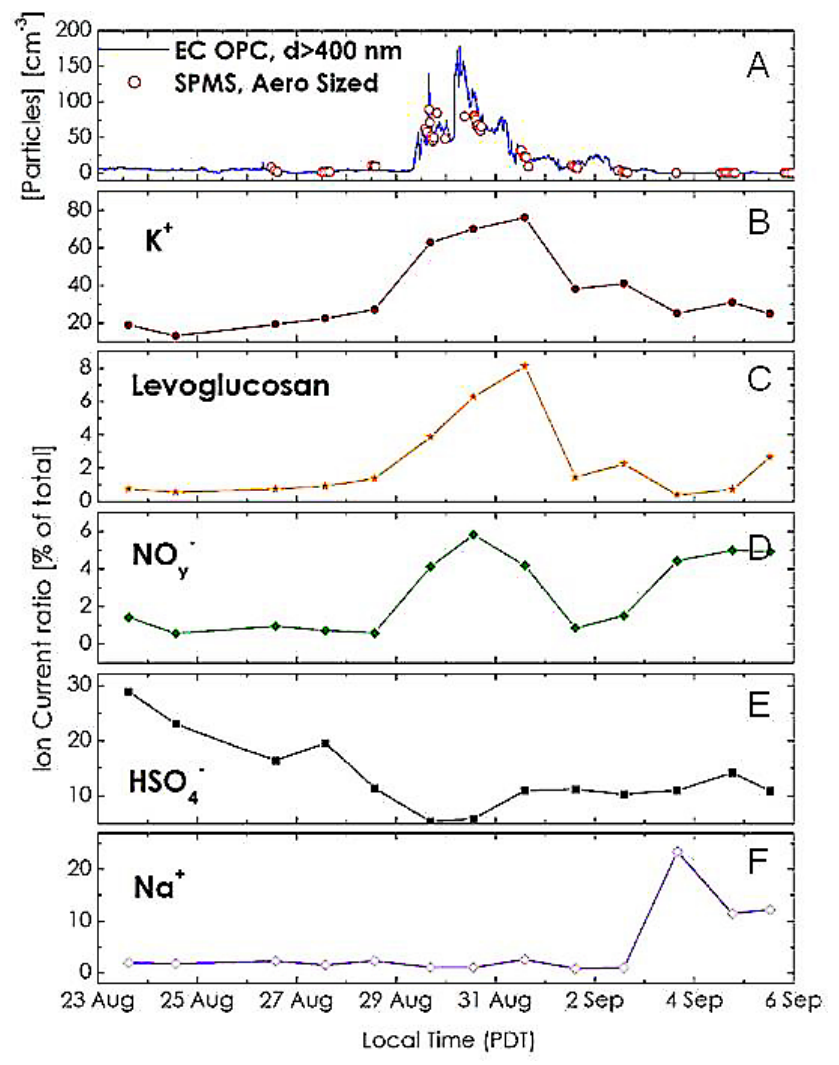

Fig. 6. (A) Time Series of total particle concentration for particles larger than $400 \mathrm{~nm}$ as measured by the EC OPC and the UBC SPMS at Whistler Peak during the week before and after the smoke event. (B-F) Time series of relative intensity of potassium, levoglucosan, nitrate, sulphate and sodium over the same time period.

careful meteorological analysis of three-dimensional motion in relation to layer structures as well as boundary layer growth. Lidar has been used in previous boundary layer studies in mountainous terrain, but in most cases the data have been collected for only short time periods via either aircraft or temporary ground installations (e.g. Reuten et al., 2005; de Wekker et al., 2004). This study confirms that permanent lidar installations in mountainous locations can add value to other atmospheric observations from the same area and are crucial to the understanding of vertical transport processes and the analysis of chemical time series.

This study also highlights the importance of synoptic scale weather patterns on the character of air masses sampled at a mountaintop observatory. Studies using a synoptic classification scheme for the European Alps have demonstrated the effects of different circulation patterns and wind directions on aerosol and trace gas measurements at the Jungfraujoch observatory in Switzerland (e.g. Lugauer et al., 1998; Forrer et al., 2000). For the Whistler site, this case is a good example of an easterly wind flow (not common at this location) transporting regionally produced aerosol loads to the site. While the Whistler observatory is well-situated to sam- ple air masses coming off the Pacific Ocean in prevailing westerlies, it is important to recognize times when the synoptic pattern produces trajectories with relatively long residence times over the North American continent. Thus, synoptic scale flow and the more local boundary layer influence should both be considered when characterizing the air mass sampled at a mountain observatory for a particular time period.

In addition to chemically confirming the presence of smoke at Whistler, deployment of a SPMS instrument at Whistler Peak represents a significant addition to the suite of instruments at the Whistler mountaintop facility. In this example, the instrument is able to not only confirm the source of local aerosol (biomass burning) but is able to provide the detailed physico-chemical signature of a regional smoke event. When combined with other aerosol measurements in southwestern BC (e.g. AERONET and CORALNet), the addition of this instrument to the Whistler suite of observations promises to significantly increase understanding of the provenance and chemical properties of aerosols in the lower FT in western Canada. On the basis of this and similar cases, future efforts will be directed toward permanent installation of a CORALNet lidar at Whistler to support the investigation of aerosol transport from hemispheric to local scales.

Acknowledgements. We thank Norm O'Neill, Alain Royer and their staff for establishing and maintaining the Saturna Island sites used in this investigation and also the Cloud Physics and Severe Weather Research Section of Environment Canada for making the Whistler ceilometer available for aerosol research through the summer of 2009. This paper has benefitted substantially from the insights of Michael Fromm and two anonymous reviewers. We are grateful for the financial and in-kind support provided by Environment Canada, the Natural Sciences and Engineering Research Council, the BC Ministry of Environment, The Canadian Foundation for Innovation, and the Canadian Foundation for Climate and Atmospheric Sciences. Special thanks also go to the University of British Columbia, particularly Seane Trehearne at Totem Field, and to Michael Travis and Bernard Firanski of Environment Canada.

Edited by: A. Laaksonen

\section{References}

Amiridis, V., Balis, D. S., Giannakaki, E., Stohl, A., Kazadzis, S., Koukouli, M. E., and Zanis, P.: Optical characteristics of biomass burning aerosols over Southeastern Europe determined from UVRaman lidar measurements, Atmos. Chem. Phys., 9, 2431-2440, doi:10.5194/acp-9-2431-2009, 2009.

Baltensperger, U., Gäggeler, H., Jost, D., Lugauer, M., Schwikowski, M., Weingartner, E., and Seibert, P.: Aerosol climatology at the high-alpine site Jungfraujoch, Switzerland, J. Geophys. Res., 102, 19707-19715, 1997.

Campuzano-Jost, P. and Bertram, A. K.: An ion trap based single particle MS for high altitude research, in preparation, 2010. 
De Wekker, S. F., Steyn, D., and Nyeki, S.: A comparison of aerosol-layer and convective boundary-layer structure over a mountain range during STAAARTE '97, Bound.-Lay. Meteorol., 113, 249-271, 2004.

Dubovik, O., Smirnov, A., Holben, B. N., King, M. D., Kaufman, Y. J., Eck, T. F., and Slutsker, I.: Accuracy assessments of aerosol optical properties retrieved from Aerosol Robotic Network (AERONET) sun and sky radiance measurements, J. Geophys. Res., 105(D8), 9791-9806, 2000.

Emeis, S., Münkel, C., Vogt, S., Müller, W. J., and Schäfer, K.: Atmospheric boundary-layer structure from simultaneous SODAR, RASS, and ceilometer measurements, Atmos. Environ., 38(2), 273-286, 2004.

Forrer, J., Rüttimann, R., Schneiter, D., Fischer, A., Buchmann, B., and Hofer, P.: Variability of trace gas measurements at the high-alpine site Jungfraujoch caused by meteorological transport processes, J. Geophys. Res., 105, 12241-12251, 2000.

Hacker, J. P., McKendry, I. G., and Stull, R. B.: Modeled downward transport of Asian dust over Western North America during April 1998, J. Appl. Meteorol., 40, 1617-1628, 2001.

Hanna, S. J., Campuzano-Jost, P., Simpson, E. A., Robb, D. B., Burak, I., Blades, M. W., Hepburn, J. W., and Bertram, A. K.: A new broadly tunable (7.4-10.2 eV) laser based VUV light source and its first application to aerosol mass spectrometry, Int. J. Mass Spectrom. 279, 134-146, 2009.

Hudson, P. K., Murphy, D. M., Cziczo, D. J., Thomson, D. S., deGouw, J. A., Warneke, C., Holloway, J., Jost, H.-J., and Hübler, G.: Biomass burning particle measurements: Characteristic composition and chemical processing, J. Geophys. Res., 109, D23S27, doi:10.1029/2003JD004398, 2004.

IPCC a: Contribution of Working Group I to the Fourth Assessment Report of the Intergovernmental Panel on Climate Change, edited by: Solomon, S., Qin, D., Manning, M., Chen, Z., Marquis, M., Averyt, K. B., Tignor, M., and Miller, H. L., Cambridge University Press, Cambridge, United Kingdom and New York, NY, USA, 2007.

IPCC b: Contribution of Working Group II to the Fourth Assessment Report of the Intergovernmental Panel on Climate Change, edited by: Parry, M. L., Canziani, O. F., Palutikof, J. P., van der Linden, P. J., and Hanson, C. E., Cambridge University Press, Cambridge, United Kingdom and New York, NY, USA, 2007.

Leaitch, W. R., Macdonald, A. M., Anlauf, K. G., Liu, P. S. K., Toom-Sauntry, D., Li, S.-M., Liggio, J., Hayden, K., Wasey, M. A., Russell, L. M., Takahama, S., Liu, S., van Donkelaar, A., Duck, T., Martin, R. V., Zhang, Q., Sun, Y., McKendry, I., Shantz, N. C., and Cubison, M.: Evidence for Asian dust effects from aerosol plume measurements during INTEXB 2006 near Whistler, BC, Atmos. Chem. Phys., 9, 3523-3546, doi:10.5194/acp-9-3523-2009, 2009.

Lugauer, M., Baltensperger, U., Furger, M., Gäggeler, H., Jost, D., Schwikowski, M., and Wanner, H.: Aerosol transport to the high Alpine sites Jungfraujoch (3454 m asl) and Colle Gnifetti (4452 m a.s.1.), Tellus B, 50B, 76-92, 1998.

McKendry, I. G. and Lundgren, J.: Tropospheric layering of ozone in regions of urbanised complex and/or coastal terrain - a review, Prog. Phys. Geogr., 24, 359-384, 2000.

McKendry, I. G., Strawbridge, K., O'Neill, N., Macdonald, A. M., Liu, P., Jaegle, L., Jaffe, D., Fairlie, D., Anlauf, K., and Westphal, D.: A Case of Trans-Pacific Transport of Saharan
Dust to Western North America, J. Geophys. Res., 112, D01103, doi:10.1029/2006JD007129, 2007.

McKendry, I. G., Macdonald, A. M., Leaitch, W. R., van Donkelaar, A., Zhang, Q., Duck, T., and Martin, R. V.: Trans-Pacific dust events observed at Whistler, British Columbia during INTEXB, Atmos. Chem. Phys., 8, 6297-6307, doi:10.5194/acp-8-62972008, 2008.

McKendry, I. G., van der Kamp, D., Strawbridge, K. B., Christen, A., and Crawford, B.: Simultaneous observations of boundarylayer aerosol layers with CL31 ceilometer and 1064/532 nm lidar, Atmos. Environ., 43(36), 5847-5852, 2009.

McKendry, I. G., Strawbridge, K., Karumudi, M. L., O’Neill, N., Macdonald, A. M., Leaitch, R., Jaffe, D., Sharma, S., Sheridan, P., and Ogren, J.: Californian wildfire plumes over Southwestern British Columbia: lidar, sunphotometry, and mountaintop chemistry observations, Atmos. Chem. Phys. Discuss., 10, 21047-21075, doi:10.5194/acpd-10-21047-2010, 2010.

Münkel, C., Eresmaa, N., Räsänen, J., and Karppinen, A.: Retrieval of mixing height and dust concentration with lidar ceilometer, Bound.-Lay. Meteorol., 124(1), 117-128, 2007.

Murphy, D. M., Cziczo, D. J., Froyd, K. D., Hudson, P. K., Matthew, B. M., Middlebrook, A. M., Peltier, R. E., Sullivan, A., Thomson, D. S., and Weber, R. J.: Single-particle mass spectrometry of tropospheric aerosol particles, J. Geophys. Res., 111, D23S32, doi:10.1029/2006JD007340, 2006.

Obrist, D., Hallar, A. G., McCubbin, I., Stephens, B. B., and Rahn, T.: Atmospheric mercury concentrations at Storm Peak Laboratory in the Rocky Mountains: Evidence for long-range transport from Asia, boundary layer contributions, and plant mercury uptake, Atmos. Environ., 42, 7579-7589, 2008.

Qin, X. and Prather, K. A.: Impact of biomass emissions on particle chemistry during the California Regional Particulate Air Quality Study, Int. J. Mass Spectrom., 258, 142-150, 2006.

Räsänen, J., Lönnqvist, J., and Piironen, A. K.: Urban boundary layer measurements with a commercial ceilometer. In: Proc. 3rd Symp. on Urban Environment 15 to 18 August 2000, Davis CA, American Meteorological Society, Boston, vol. 5.1, 34, 2000.

Reid, J. S., Eck, T. F., Christopher, S. A., Koppmann, R., Dubovik, O., Eleuterio, D. P., Holben, B. N., Reid, E. A., and Zhang, J.: A review of biomass burning emissions part III: intensive optical properties of biomass burning particles, Atmos. Chem. Phys., 5, 827-849, doi:10.5194/acp-5-827-2005, 2005a.

Reid, J. S., Koppmann, R., Eck, T. F., and Eleuterio, D. P.: A review of biomass burning emissions part II: intensive physical properties of biomass burning particles, Atmos. Chem. Phys., 5, 799825, doi:10.5194/acp-5-799-2005, 2005b.

Reuten, C., Steyn, D., Strawbridge, K., and Bovis, P.: Observations of the relation between upslope flows and the convective boundary layer in steep terrain, Bound.-Lay. Meteorol., 116, 37-61, 2005.

Silva, P. J., Liu, D.-Y., Noble, C. A., and Prather, K. A.: Size and Chemical Characterization of Individual Particles Resulting from Biomass- burning of Local Southern California Species, Environ. Sci. Technol., 33(18), 3068-3076, 1999.

Simpson, E. A., Campuzano-Jost, P., Hanna, S. J., Robb, D. B., Hepburn, J. W., Blades, M. W., and Bertram, A. K.: A laser desorption-electron impact ionization ion trap mass spectrometer for real-time analysis of single atmospheric particles, Int. J. Mass Spectrom., 281, 140-149, 2009. 
Su, Y., Sipin, M. F., Furutanu, H., and Prather, K. A.: Development and Characterization of an Aerosol Time-of-Flight Mass Spectrometer with Increased Detection Efficiency, Anal. Chem., 76, 712-719, 2004.

Thulasiraman, S., O’Neill, N. T., Royer, A., Holben, B. N., Westphal, D. L., and McArthur, L. J. B.: Sunphotometric observations of the 2001 Asian dust storm over Canada and the U.S., Geophys. Res. Lett., 29(8), 1255, doi:10.1029/2001GL014188, 2002.

van der Kamp, D., McKendry, I. G., Wong, M., and Stull, R.: Lidar Ceilometer Observations and Modeling of a Fireworks Plume in Vancouver, British Columbia, Atmos. Environ., 42, 7174-7178, 2008.

van der Kamp, D. and McKendry, I. G.: Comparison of Tethered Balloon Vertical Profiles of Particulate Matter Size Distributions with Lidar Ceilometer Backscatter in the Nocturnal Urban Boundary Layer, Int. J. Environ. Pollut., 41(1/2), 155-165, 2010 .
Weiss-Penzias, P., Jaffe, D. A., Swartzendruber, P., Dennison, J. B., Chand, D., Hafner, W., and Prestbo, E.: Observations of Asian air pollution in the free troposphere at Mount Bachelor Observatory during the spring of 2004, J. Geophys. Res., 111, D10304, doi:10.1029/2005JD006522, 2006.

Whiteman, C. D.: Mountain Meteorology: Fundamentals and Applications Oxford University Press, 355, 2000.

Zephoris, M., Holin, H., Lavie, F., Cenac, N., Cluzeau, M., Delas, O., Eideliman, F., Gagneux, J., Gander, A., and Thibord, C.: Ceilometer observations of aerosol layer structure above the Petit Luberon during Escompte's IOP 2, Atmos. Res., 74(1-4), 581-595, 2005. 